\title{
ASSISTIVE TECHNOLOGIES FOR AGED CARE: SUPPORTIVE OR EMPOWERING?
}

\author{
Suchada Vichitvanichphong \\ University of the Sunshine Coast \\ Suchada.Vichitvanichphong@ research.usc.edu.au
}

Don Kerr

University of the Sunshine Coast

dkerr@usc.edu.au

Amir Talaei-Khoei

University of Technology Sydney

Amir.Talaei-Khoei@uts.edu.au

Amir Hossein Ghapanchi

Griffith University

a.ghapanchi@griffith.edu.au

\begin{abstract}
The main objective of this paper is to explore the potentials of assistive technologies to support seniors' independent living. The work looks at two salient aspects of utilizing technologies for elderly, namely direct support and empowering technologies. The research undertakes a comprehensive analysis of attempts that have been made through investigation of the literature. For this purpose, a realist review of relevant papers published since 2000 has been conducted. The paper concludes that although much research in this area targets the direct support for older adults, the effective use of technologies to maintain seniors' physical and cognitive abilities requires further investigations. This can provide avenues of opportunities that would empower seniors for their independent living.
\end{abstract}

\section{INTRODUCTION}

Owing to a substantial decline in the age-specific mortality, the world's population is ageing rapidly. In $2012,6.9 \%$ of the world population were more than 65 years old, and this is estimated to increase to around $20 \%$ by 2050 (OECD, 2012). What was before a small number of exceptional old individuals is rapidly becoming a whole new generation for families and the society? The elderly have lived long enough to have acquired, on average, several medical conditions, and a range of age-associated impairments of bodily and mental functions. This has led to concern as to whether existing care provision will cope with the predicted future demand (Australian Nursing Federation, 2012). Also, it is commonly believed that seniors would like to live independently at their home (Porteus and Brownse, 2000). However, the issue is the fact that whether their home is compatible with their physical and cognitive conditions (Leeson et al., 2004). In this perspective, assistive technologies provide aid for elderly, but are underutilized to offer effective training of skills that are required for independent living.

Marshall, (1997) (Marshall, 1997b) has defined assistive technology in the context of aiding seniors with disabilities as "any item, piece of equipment, product or system, whether acquired commercially, off-the-shelf, modified or customized, that is used to increase, maintain or improve functional capabilities of individuals with cognitive, physical or communication disabilities". The above definition has an emphasis on disabilities in seniors. A more recent definition has been given by the Australian Dementia Resources Guide (DOHA, 2008). This guide defines "assistive technologies as a product, equipment or device, usually electronic or mechanical in nature, which helps people with disabilities to maintain their independence or improve their quality of life". This definition has extended the use of 
assistive technologies from devices to help older adults with disabilities to products facilitating seniors' with their daily life activities. Our definition of assistive technology is most closely related to the Dementia Resources Guide definition, although we look at assistive technologies in a boarder sense than only being used for dementia patients.

While recent advancements in Information Technology (IT) have resulted in cheap off-the-shelf products that can have potential to assist older people in their daily life activities at their home (Miskelly, 2001), less is known on how these technologies can assist seniors. In other words, despite the existing body of literature in technologies that can assist elderly, the bigger picture of research on what are the real potentials for these technologies is missing. Our exploratory search on application of assistive technologies in aged care (Vichitvanichphong et al., 2013) has shown that there are very limited studies that aim to empowering seniors by training and maintaining the skills that are necessary for independent lifestyle. Instead, work around this topic has been based more on introducing technologies that directly support elderly in their daily living.

In response to the above mentioned concerns, this paper aims to look at the technologies that have been used for aged care and identifies the potentials of these technologies. The ultimate aim of this work is to better understand how technologies can be utilized in this setting. Therefore, researchers and professionals would be aware of salient approaches that assistive technologies can be effectively utilized for seniors. This paper seeks to answer the following research questions:

\section{What are the potentials of assistive technologies for seniors' independent living?}

For this to be answered, we seek to identify the available technologies. We also look at the attributes of these technologies and how they open up potential opportunities for effective approaches in utilising technologies in aged care.

In order to answer the question, the present research has taken a realist review approach as suggested by (Pawson et al., 2005). We have systematically searched papers and extracted relevant data to the questions. From these papers, we have also conducted some characteristics of the research in this area e.g. research method, or geographical distribution etc.

\section{METHOD}

We customized the guidelines for realist reviews laid down by (Pawson et al., 2005). The reason why we chose to follow the realist approach was that it has been proven (Macaulay et al., 2011) as an effective way of reviewing complex interventions with social aspects, which implies to the matter of technology adoption among seniors. The realist review proposes six steps to carry out a literature review; (1) Exploratory background search to identify the relevant keywords and databases, (2) Searching for the initial list of studies, (3) Relevance appraisal, (4) Extracting data, (5) Analysis of data and finally, (6) Evaluation. In the following sections, we explain the process that we have conducted in our realist review of literature associated with the adoption of assistive technologies among seniors.

\section{Exploratory background search: identifying keywords and databases}

The first step towards searching the articles was to identify the relevant keywords and online databases. we have conducted a background survey (Vichitvanichphong et al., 2013) in two topic areas; Medical Informatics and Information Systems. These areas have been selected due to the focus of this review to the assistive technologies among seniors. An initial list of journals has been chosen from the journal classification list proposed by Excellence in Research for Australia (ERA, 2012). The relevant journals were selected and the journals with an impact factor of less than one were omitted. As such, we came up with 14 journals regarded as popular outlets of publication in this area. We have found 31 relevant papers published in these journals, since 2009. 
In order to identify the relevant keywords and related online databases, we have implemented the experimental method proposed by (Dieste et al., 2009). The method was applied in the above-mentioned 31 papers and identified most popular online databases indexing these 31 papers, also the most popular keywords relevant to "aged care" and "adoption" used with "technology".

\section{Searching the initial list of papers}

Following the search instructions given by each database and using the most popular relevant keywords identified in the background search, we required that the relevant articles contain the word "Technology" along with any of "aged care", "aged", "aging”, "senior", “old”, "elderly", “elder" or "older" in their titles, keywords, abstracts or full texts.

Eight popular databases were searched using the above keywords. The search considered titles, keywords, abstracts and full texts of papers published since 2000, inclusive and returned 723,944 articles. The distribution of papers in each database is presented in Table 1.

\section{Relevance appraisal}

In this step, the objective was to filter relevant papers from the initial list and exclude the ones which are not related to our study. This process was carried out by excluding papers based on titles, keywords, abstracts and full texts; see Figure 1. Articles that have one of the following exclusion criteria were removed:

- Did not focus on assistive technologies for aged care.

- $\quad$ Did not have any empirical evidence.

- Were in languages other than English.

- Were not in the relevant fields or could not be applied to relevant fields.

- Were not peer reviewed.

- Were not available online. 


\begin{tabular}{|c|c|c|c|c|c|c|c|}
\hline \multirow[b]{2}{*}{$\begin{array}{l}\text { Name of } \\
\text { Database }\end{array}$} & \multirow[b]{2}{*}{$\begin{array}{l}\text { Initial } \\
\text { list of } \\
\text { papers }\end{array}$} & \multicolumn{2}{|c|}{ Filtered by titles } & \multicolumn{2}{|c|}{ Filtered by abstract } & \multicolumn{2}{|c|}{ Filtered by text } \\
\hline & & $\begin{array}{l}\text { No. of } \\
\text { found } \\
\text { articles }\end{array}$ & $\begin{array}{l}\text { No. of } \\
\text { duplicate } \\
\text { articles }\end{array}$ & $\begin{array}{l}\text { No. of } \\
\text { found } \\
\text { articles }\end{array}$ & $\begin{array}{l}\text { No. of } \\
\text { duplicate } \\
\text { articles }\end{array}$ & $\begin{array}{l}\text { No. of } \\
\text { found } \\
\text { articles }\end{array}$ & $\begin{array}{l}\text { No.of } \\
\text { duplicated } \\
\text { articles }\end{array}$ \\
\hline Springer & 16,539 & 213 & 22 & 31 & 11 & 18 & 6 \\
\hline $\begin{array}{l}\text { Wiley } \\
\text { InterScience }\end{array}$ & 453,537 & 99 & 15 & 17 & 8 & 11 & 5 \\
\hline $\begin{array}{l}\text { Science } \\
\text { Direct }\end{array}$ & 11,442 & 49 & 18 & 38 & 16 & 32 & 10 \\
\hline IEEEXplor & 69,690 & 30 & 13 & 22 & 12 & 16 & 6 \\
\hline $\begin{array}{l}\text { ACM } \\
\text { Digital } \\
\text { Library }\end{array}$ & 560 & 21 & 6 & 14 & 5 & 10 & 3 \\
\hline Scirus & 94,487 & 27 & 7 & 18 & 6 & 14 & 4 \\
\hline PubMed & 10,989 & 33 & 9 & 25 & 8 & 18 & 6 \\
\hline $\begin{array}{l}\text { Google } \\
\text { Scholar }\end{array}$ & 66,700 & 160 & 122 & 48 & 16 & 39 & 14 \\
\hline Total & 723,944 & 632 & 212 & 213 & 75 & 158 & 54 \\
\hline \multicolumn{2}{|c|}{$\begin{array}{l}\text { Relevant papers by } \\
\text { deducting the } \\
\text { duplicated articles }\end{array}$} & & 20 & \multicolumn{2}{|c|}{138} & \multicolumn{2}{|c|}{104} \\
\hline
\end{tabular}

Table 1 Distribution of papers in each online database.

Among 723,944 papers indexed in the databases and searched by the keywords, 420 papers were remained after title filtering, 138 articles were remained after abstract filtering and 104 papers were identified as final list of relevant papers after reading the full texts. We also found some of the papers were indexed by multiple databases, see Table 1. It is notable that we used Zotero (http://www.zotero.org/) for reference management.

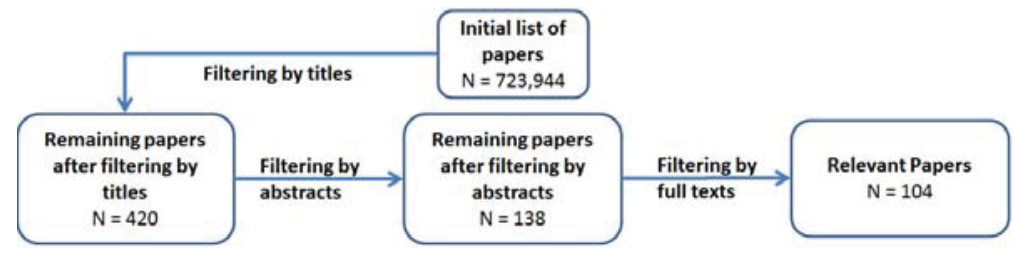

Figure 1 Relevance appraisal process

\section{Extracting data}

In the data extraction stage, key details from the selected papers were obtained. Three types of data were collected from each paper:

- Technology options: we identified what technologies have been used in each paper to assist seniors. 
- Demographics: In order to analyze the characteristics of the research in this area, we have collected demographic details such as research methods, fields of publication and geographical distribution each relevant paper.

In order to ensure the reliability of the results, we used standard critical review forms for quantitative (Law et al., 1998a) and qualitative studies (Law et al., 1998b). For mix-method studies, we completed both forms.

\section{Analysis of data}

In order to answer the research question, we identified the classification of technologies that have been used to assist elderly i.e. technology options. We also identified the main research areas. In these analyses, we used the process proposed by (Ghapanchi and Aurum, 2011). In order to answer to the research question, and identifying the technology options, the process involved extracting the terms and definitions used in the final list of selected papers, and eventually forming the primary list of technologies. It broadly categorized the factors as well as the technologies. The process is depicted in Figure 2.

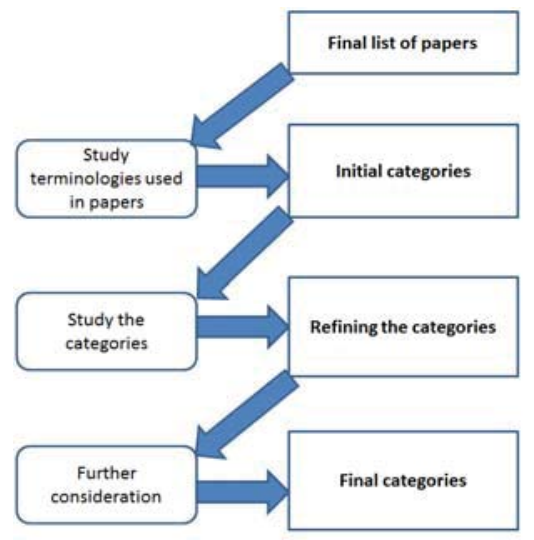

Figure 2 Data analysis process.

\section{Peer evaluation and reliability testing}

A peer review of the findings for the interventions and factors impacting the adoption of technologies among seniors was undertaken. Four experts from North America, Australia, Europe and Asia were invited to code both interventions and impacting factors of adoption into categories. The experts were chosen based on their academic knowledge and practical experience in the topic. The experts were given an instruction sheet including the description of all the items as well as an answer sheet in which they were asked to map the items into the proposed categories.

A reliability test was then undertaken based on proportional reduction in loss (PRL) reliability indicator introduced by (Rust and Cooil, 1994). PRL is used to assess the consensus between judges who are invited to code a number of elements into exclusive categories. In addition to the four experts, we have considered the proposed contributions of this work as one coding. Therefore, the total number of judges was five. Inter-judge agreement was measured by dividing the total pair-wise agreements by the total pair-wise decisions. Having five judges onboard; in assigning each item into a category, a total number of 10 pair-wise decisions were made. The consensus of assigning an item to a category was the most frequently selected choice by the five judges. The reliability for each contribution was calculated based on the value of Inter-judge agreement. The number of pair-wise agreements was 169 out of the total 
270 pair-wise decisions, which calculates 0.62 inter-judge agreements and $78 \%$ reliability of the results. Therefore, based on (Rust and Cooil, 1994), the reliabilities of contribution in this paper are acceptable.

\section{FINDINGS}

In this section, we present the results of our investigation on the technology options, and demographics of the research in assistive technologies for aged care.

\section{Technology options}

As described in this section, we have categorized technologies that have been adopted in 104 relevant papers into 7 categories; general purpose ICT, social media, games, robots, online information services, smart home and remote care, and supportive devices.

It was found that general purpose ICT and smart home and remote care were the technologies that most of the interventions have been focused, see Figure 3.

Number of Publications vs Technology Options

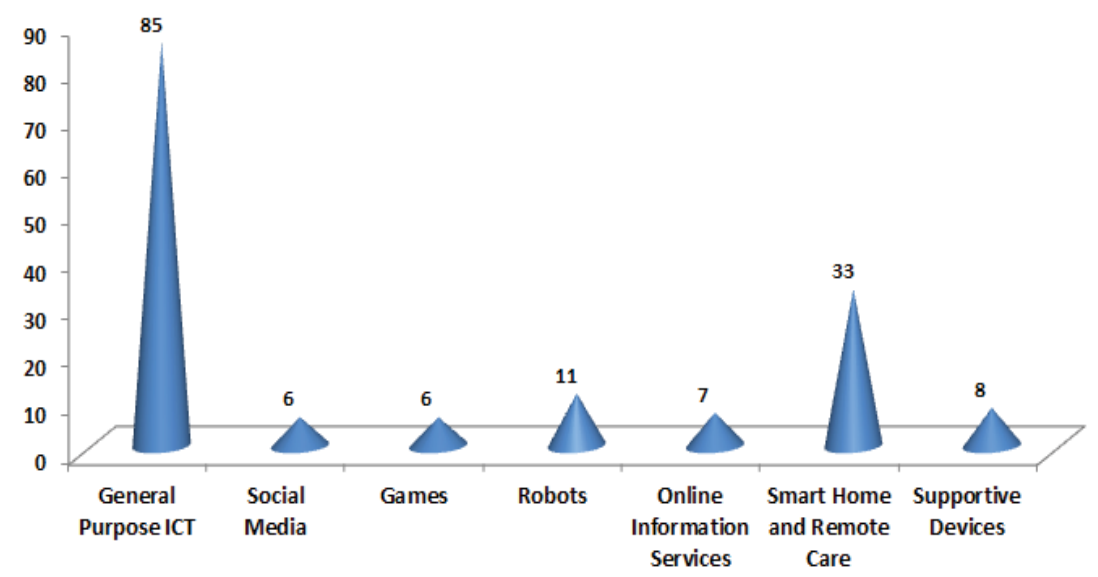

Figure 3 Distribution of papers over different technology options

The first category is ICT in general purpose and this includes technologies such as mobile phones, the Internet, email, etc. Seniors have been using these technologies to cope with the transition period or life style change after retirement or to communicate with family, friends and caregivers; see Table 3. These technologies are well established and not considered innovative any more. We consider the use and adoption of these well-established technologies to be relatively straightforward and requiring more of an educational training approach as community pressure will play an important part in older people adopting and using these technologies. These devices are becoming increasingly mainstream and part of everyday society much like television or the home phone. 


\begin{tabular}{|c|c|}
\hline Technology & Sample of Adoption \\
\hline \multirow{3}{*}{ Email } & $\begin{array}{l}\text { "...Elderly can enhance their self-esteem and decrease loneliness by remaining in contact } \\
\text { with the world via e-mail. The Internet and e-mail are means to keep in touch with the } \\
\text { world... (Kiel, 2005)" }\end{array}$ \\
\hline & $\begin{array}{l}\text { Other(s): (Hiroyuki Umemuro, 2004); (Haase et al., 2012); (Adams et al., 2005); (Selwyn } \\
\text { et al., 2003); (Melenhorst et al., 2006); (Rosenberg et al., 2009); (Singh et al., 2009) }\end{array}$ \\
\hline & $\begin{array}{l}\text { "...Using the mobile health services/ smart phone will improve seniors' life quality and } \\
\text { make seniors more effective in their lives. For example, seniors use mobile phone to } \\
\text { communicate with family, friends, and carers any time they need... (Guo et al., 2013)" }\end{array}$ \\
\hline $\begin{array}{l}\text { Mobile/smart } \\
\text { phone }\end{array}$ & $\begin{array}{l}\text { Other(s): (Conci et al., 2009); (Xue et al., 2012); (Ahn et al., 2008); (Barnard et al., 2013); } \\
\text { (Renaud and van Biljon, 2008); (Häikiö et al., 2007); (Xue et al., 2012); (Mallenius et al., } \\
\text { 2007); (Walsh and Callan, 2011); (Melenhorst et al., 2001); (Haase et al., 2012); } \\
\text { (Boontarig et al., 2012); (Kubik, 2009); ((Boni) Li and Perkins, 2007); (Neves, 2012); } \\
\text { (Rosenberg et al., 2009); (Hardill and Olphert, 2012); (Salovaara et al., 2010); (Copolillo } \\
\text { and Prohaska, 2001); (Biljon and Renaud, 2008); }\end{array}$ \\
\hline Digital camera & $\begin{array}{l}\text { "...Older adults is able to increase their memories as well as enhance their quality of life } \\
\text { through using digital camera...(Salovaara et al., 2010)" }\end{array}$ \\
\hline MP3 & $\begin{array}{l}\text { "...Listening to music on MP3 player instead of an old radio help seniors to perform task } \\
\text { better and enhance independence and quality of life...(Salovaara et al., 2010)" }\end{array}$ \\
\hline GPS & $\begin{array}{l}\text { "...The Global Positioning System (GPS) provides seniors advanced means of } \\
\text { communication and support the use of different modalities which makes seniors' lives a } \\
\text { lot easier...(Salovaara et al., 2010)" }\end{array}$ \\
\hline \multirow[t]{2}{*}{$\begin{array}{l}\text { Personal Digital } \\
\text { Assistant (PDA) }\end{array}$} & $\begin{array}{l}\text { "...PDA helps seniors to execute day-to-day duties as well as storage information, which } \\
\text { is an important tool for managing their lives... (Wilkowska and Ziefle, 2009)" }\end{array}$ \\
\hline & $\begin{array}{l}\text { "...Using computer makes older adults independent. Computers can fulfill both types of } \\
\text { activities—acting for some people as a means to 'keep the brain ticking' and 'filling a } \\
\text { void in seniors' lives'...(Selwyn, 2004)" }\end{array}$ \\
\hline \multirow[t]{2}{*}{ Computer } & $\begin{array}{l}\text { Other(s): (Aula, 2005); (Cameron et al., 2001); (Ahn et al., 2008); (Mitzner et al., 2010); } \\
\text { (Abdullah et al., 2011); (Czaja et al., 2008); (Giuliani et al., 2005); (Lam and Lee, 2006); } \\
\text { (Walsh and Callan, 2011); (Kiel, 2005); (Melenhorst et al., 2001); (Burnett et al., 2011); } \\
\text { (Czaja et al., 2006); (Haase et al., 2012); (Hernández-Encuentra et al., 2009); (Morris et } \\
\text { al., 2007); ((Boni) Li and Perkins, 2007); (Neves, 2012); (Selwyn et al., 2003); } \\
\text { (Rosenberg et al., 2009); (Wood et al., 2005); (Karavidas et al., 2005); (Sayago et al., } \\
\text { 2011); (Carpenter and Buday, 2007); (Salovaara et al., 2010); (H. Umemuro, 2004) }\end{array}$ \\
\hline & $\begin{array}{l}\text { "...Functional abilities in daily activities of older adults can be boosted by using the } \\
\text { Internet. Older adults use the Internet for communication, seeking information, } \\
\text { commercial purposes, etc. Eventually, using the Internet can enhance seniors' well- } \\
\text { being...(Sum et al., 2008) }\end{array}$ \\
\hline Internet & $\begin{array}{l}\text { Other(s): (Nayak et al., 2010); (Aula, 2005); (Cameron et al., 2001); (Sum et al., 2009); } \\
\text { (Hanson, 2010); (Pan and Jordan-Marsh, 2010); (Mitzner et al., 2010); (Abdullah et al., } \\
\text { 2011); (El-Attar et al., 2005); (Czaja et al., 2008);(Lam and Lee, 2006); (Kiel, 2005); } \\
\text { (Melenhorst et al., 2001); (Czaja et al., 2006); (Haase et al., 2012); (Hernández-Encuentra } \\
\text { et al., 2009); (Morris et al., 2007); (Adams et al., 2005); (Eastman and Iyer, 2004); } \\
\text { (Neves, 2012); (Melenhorst and Bouwhuis, 2004); (Rosenberg et al., 2009); (Sum et al., } \\
\text { 2008); (Choi and Dinitto, 2013) }\end{array}$ \\
\hline
\end{tabular}

Table 3 Technology options: general purpose ICT 
The second category is social media. Increasingly, we see seniors becoming isolated from social activities, usually after the loss of a partner and this, combined with the desire to live independently in their own home, leads to a loss of previously established social networks. Researchers have used social media to engage seniors in the community and to increase their social interactions by staying in touch with people, establishing friendships and gaining information, even sharing thoughts and experiences; see Table 4. Social media technology is relatively new and requires a mindset of ubiquitous access and this usually entails the use of newer technologies such as tablets, smartphones or laptop computers to be truly effective. The adoption of these newer technologies could be more problematic for older people and there needs to be well thought out processes in place to incentivize adoption for this older generation.

\begin{tabular}{|c|c|}
\hline Technology & Sample of Adoption \\
\hline \multirow[t]{2}{*}{$\begin{array}{l}\text { Online social } \\
\text { network }\end{array}$} & $\begin{array}{l}\text { "...To decrease loneliness as well as enhance (health) communication for older adults, } \\
\text { social network or social media is a great tool used by them. Using online social } \\
\text { network, particularly comprehensive social network platform like facebook, allows } \\
\text { seniors to keep up in the day to day lives of important others, for example...(Braun, } \\
\text { 2013)" }\end{array}$ \\
\hline & Other $(s)$ : (Heinz et al., 2013) \\
\hline \multirow[t]{2}{*}{$\begin{array}{l}\text { Online } \\
\text { community }\end{array}$} & $\begin{array}{l}\text { "... Online community is increasingly being incorporated into the everyday routines of } \\
\text { older adults. Engaging in online community can improve seniors' quality of life and } \\
\text { decrease loneliness...(Chung et al., 2010)" }\end{array}$ \\
\hline & Other(s): (Ryu et al., 2009); (Wong et al., 2012) \\
\hline
\end{tabular}

Table 4 Technology options: social media

Another category is games; either video games or mobile games. Many older adults have a connection with traditional games such as card games like bridge and board games like Monopoly. This could easily be extended to the electronic media and research has shown that older adults can use video or mobile games as a therapy tool and for entertainment, relaxation and socialization; see Table 5. We found games, because of their interactive nature can also be used to improve seniors' cognitive skills and this can help them in their functioning for their daily lives. Cognitive research has found that this could be a very significant feature in improving daily living for seniors and that gaming can provide a proactive approach by improving seniors' living skills. In fact, this approach could provide brain training before the elderly start to need assistance and thus reduce the resources needed to facilitate daily living further down the track. We will discuss this aspect later. 


\begin{tabular}{|c|c|}
\hline Technology & Sample of Adoption \\
\hline \multirow[t]{2}{*}{ Video game } & $\begin{array}{l}\text { "...Video games increasingly used as a therapeutic tool in health and aged care } \\
\text { settings. The use of interactive video games as a therapy tool for addressing } \\
\text { both physical and cognitive function is a growing trend in the health and aged } \\
\text { care sector ...(Laver et al., 2011)" }\end{array}$ \\
\hline & $\begin{array}{l}\text { Other(s): (McKay and Maki, 2010); (McLaughlin et al., 2012); (Heinz et al., } \\
\text { 2013); (Wood et al., 2005) }\end{array}$ \\
\hline Mobile game & $\begin{array}{l}\text { "...Mobile games can benefit seniors in terms of entertainment and relaxation, } \\
\text { socialization, mental challenges and physical fitness...(Chu Yew Yee et al., } \\
2010) \text { " }\end{array}$ \\
\hline
\end{tabular}

Table 5 Technology options: Games

Robots are also a well-known technology option in this research area. Social robots have been used in health-related settings (see Table 6) and research has found that for seniors to adopt robots in their daily lives, they need to build a long term relationship with the robot. Intelligent, interactive social software can assist seniors in an interactive way and help them with daily living chores. Social robots are hardware robots that physically assist the elderly. This area of research looks promising; however there are major obstacles with respect to adoption that needs to be overcome. For example many older people would have problems with the concept of building a long term relationship with a machine (robot) and this concept may need to be modified to allow for human wants and emotional needs. This is very culturally and country specific however, the level of acceptance of long term machine/people relations could vary according to cultural norms.

\begin{tabular}{|c|c|}
\hline Technology & Sample of Adoption \\
\hline \multirow[t]{2}{*}{$\begin{array}{l}\text { Interactive } \\
\text { social software }\end{array}$} & $\begin{array}{l}\text { "...Using interactive social software at home as assisted therapy and physical and } \\
\text { cognitive assistant can help seniors to improve quality of life, execute day-to-day } \\
\text { activities as well as mental health...(Heerink et al., 2010)" }\end{array}$ \\
\hline & Other $(s)$ : (Bickmore et al., 2005b) \\
\hline \multirow[t]{2}{*}{ Social robot } & $\begin{array}{l}\text { "... Social robots are looked upon as potential aids to improve the quality of life of } \\
\text { older adults, help them live independently and help relieve the stress of their } \\
\text { caregivers...(Klamer and Ben Allouch, 2010)" }\end{array}$ \\
\hline & $\begin{array}{l}\text { Other }(s) \text { : (M. Heerink et al., 2008); (Heerink, 2011); (Heerink et al., 2006); ( } \mathrm{Ng} \text { et al., } \\
\text { 2012); (Smarr et al., 2012); (Marcel Heerink et al., 2008); (MITZNER et al., 2011); } \\
\text { (Neven, 2010) }\end{array}$ \\
\hline
\end{tabular}

Table 6 Technology options: robots

As seen in Table 7, it was also found that online information services have been popularly used in this cohort e.g. using online health service to seek and update health information, electronic health records and to make health information more accessible to patients for the management of chronic conditions. The acceptance of these services would be very much associated with context. For example, a healthy person would find little need to access information on diabetes, unless they receive a diagnosis of the disease so we would expect high adoption rates for people suffering chronic disease, especially if they are having difficulty in managing the condition. 


\begin{tabular}{|c|c|}
\hline Technology & Sample of Adoption \\
\hline \multirow{2}{*}{$\begin{array}{l}\text { Online health } \\
\text { services }\end{array}$} & $\begin{array}{l}\text { "...Online health services aid older adults to maintain their independence and quality } \\
\text { of life...(Ryu et al., 2009)" }\end{array}$ \\
\hline & Other $(s)$ : (Steele et al., 2009a), (Heinz et al., 2013) \\
\hline $\begin{array}{l}\text { Electronic } \\
\text { health records }\end{array}$ & $\begin{array}{l}\text { "...Electronic personal health records (PHRs) have the potential to both make health } \\
\text { information more accessible to patients and function as a decision-support system for } \\
\text { patients managing chronic conditions. Elder people tend to use PHRs to help them to } \\
\text { manage in health related information, which is convenient, beneficial, and productive } \\
\text { in comparison to the paper based...(Price et al., 2013)" }\end{array}$ \\
\hline \multirow[t]{2}{*}{$\begin{array}{l}\text { Online daily } \\
\text { services }\end{array}$} & $\begin{array}{l}\text { "... Older adults use eService to shop, check prices, choose shipping methods and then } \\
\text { pay and complete the transaction online which help them to increase self-actualization } \\
\text { and independence...(McCloskey, 2006)" }\end{array}$ \\
\hline & Other $(s)$ : (Phan \\
\hline \multirow[t]{2}{*}{$\begin{array}{l}\text { Online } \\
\text { learning }\end{array}$} & $\begin{array}{l}\text { "...Online learning is a great tool to empower adult learner. Seniors use online learning } \\
\text { to improve cognitive abilities, maintain independence and enhance their quality of } \\
\text { life...(Chu, 2010)" }\end{array}$ \\
\hline & Table 7 Technology options: online information services \\
\hline \multicolumn{2}{|c|}{$\begin{array}{l}\text { The Smart home and remote care technologies are also used to help seniors balance safety and } \\
\text { independence through remote monitoring, motion detecting sensors and fall alarms technology. } \\
\text { Furthermore, telecare has been used for balancing safety and independence purposes and like the smart } \\
\text { home products it includes the provision of support for seniors who have dementia; see Table 8. One of } \\
\text { the interesting interventions is to use motion detection sensors to monitor seniors' movement around } \\
\text { the house, while living alone, for two purposes: (A) to monitor elderly and automatically detect their } \\
\text { falls, and inform the authority, family or friend for primary aid (Sarkisian et al., 2003), (B) to monitor } \\
\text { seniors and automatically notice any radical changes in their functional or movement abilities, which } \\
\text { may need serious and further treatments (Goins et al., 2010). These technologies provide direct } \\
\text { assistance to the elderly and are usually adopted with the thought that there is no other option but to } \\
\text { adopt. Usually these devices are installed with the ultimatum (from family and friends or health } \\
\text { authorities) that if it is not adopted the aged person will have to leave their home and go into a residential } \\
\text { care facility. This can force the individual into acceptance depending on how much they value their } \\
\text { independence. }\end{array}$} \\
\hline
\end{tabular}




\begin{tabular}{|c|c|}
\hline Technology & Sample of Adoption \\
\hline \multirow[b]{2}{*}{ Remote monitoring } & $\begin{array}{l}\text { "...Remote monitoring technology install and operate in seniors' homes with the } \\
\text { purpose of improving their quality of life and monitoring their health } \\
\text { status...(DEMIRIS et al., 2004)" }\end{array}$ \\
\hline & $\begin{array}{l}\text { Other(s): (Ahn et al., 2008); (Courtney, 2008); (Mitzner et al., 2010); (Conci et al., } \\
\text { 2010); (Wong et al., 2012); (McCREADIE and Tinker, 2005); (van Hoof et al., } \\
\text { 2011); (Courtney et al., 2008); (Mynatt et al., 2004); (Goins et al., 2010); (Steele et } \\
\text { al., 2009b); (Ahn et al., 2008); (Steele et al., 2006); (Beer and Takayama, 2011); } \\
\text { (Wong et al., 2012); (Or et al., 2011); (Bickmore et al., 2005a); (Selwyn et al., 2003) }\end{array}$ \\
\hline \multirow[t]{2}{*}{$\begin{array}{l}\text { Motion Detecting } \\
\text { sensor }\end{array}$} & $\begin{array}{l}\text { "...Elderly people perceive an intelligent system, motion detecting sensor, } \\
\text { embedded in their home, which surround humans in their daily lives and activities } \\
\text { and should enable them to live independently longer...(Zaad and Allouch, 2008)" }\end{array}$ \\
\hline & Other $(s)$ : (Sarkisian et al., 2003); (Goins et al., 2010) \\
\hline $\begin{array}{l}\text { Surveillance } \\
\text { camera }\end{array}$ & $\begin{array}{l}\text { "...Using surveillance cameras at seniors' home will assist to prevent them from } \\
\text { accident, injury, illness or other ailment that effects mobility...(Sarkisian et al., } \\
2003) \text { " }\end{array}$ \\
\hline Recording device & $\begin{array}{l}\text { "...Installing recording devices at seniors' home will assist to prevent them from } \\
\text { accident, injury, illness or other ailment that effects mobility...(Sarkisian et al., } \\
2003) \text { " }\end{array}$ \\
\hline \multirow[t]{2}{*}{ Flood alarm } & $\begin{array}{l}\text { "...Elderly people install flood alarm at their home to enhance quality of life and } \\
\text { safety purposes...(Ahn et al., 2008)" }\end{array}$ \\
\hline & $\begin{array}{l}\text { "...Seniors use home telecare as an instrumental in improving independence and } \\
\text { safety...(Peeters et al., 2012)" }\end{array}$ \\
\hline Telecare & $\begin{array}{l}\text { Other }(s) \text { : (Mahoney, 2010); (Huang, 2011); (Lai et al., 2010); (Walsh and Callan, } \\
\text { 2011); (Peeters et al., 2012); (Demiris et al., 2013); (Heinz et al., 2013) }\end{array}$ \\
\hline
\end{tabular}

Table 8 Technology options: smart home and remote care

We have also found that older adults have been using supportive devices for their functional ability; see Table 9. Medicine reminder, hearing assistance technologies and rehabilitation assistive devices are some examples of these devices. These devices may be more applicable for older people living at home, for example a medicine reminder may not be as useful in a residential care setting with health care professionals providing constant reminders and maybe even direct medicine dispensing to individual patients. Again these are direct assistance technologies and may not be needed as early in a patient's life if indirect methods such as brain training through games are used to improve memory and daily living skills. 


\begin{tabular}{|c|c|}
\hline Technology & Sample of Adoption \\
\hline \multirow[t]{2}{*}{$\begin{array}{l}\text { Medication reminder } \\
\text { device }\end{array}$} & $\begin{array}{l}\text { "...Older adults with multiple chronic conditions face the complex task of } \\
\text { medication management involving multiple medications of varying doses at } \\
\text { different times. Using medication reminder devices aid older adults to manage their } \\
\text { medications....(Reeder et al., 2013)" }\end{array}$ \\
\hline & Other $(s)$ : (Stojmenova et al., 2013); (Wong et al., 2012) \\
\hline $\begin{array}{l}\text { Hearing assistance } \\
\text { devices }\end{array}$ & $\begin{array}{l}\text { "...Hearing assistance devices help elderly people hear better in order to maintain } \\
\text { independence and enhance their quality of life...(Southall et al., 2006)" }\end{array}$ \\
\hline \multirow{2}{*}{$\begin{array}{l}\text { Rehabilitation } \\
\text { assistance devices }\end{array}$} & $\begin{array}{l}\text { "...Seniors appreciate using rehabilitation assistance devices due to benefits for } \\
\text { mobility, confidence, safety and independence... (Smith et al., 2002)" }\end{array}$ \\
\hline & $\begin{array}{l}\text { Other }(s) \text { : (Mitzner et al., 2010); (Sintonen and Immonen, 2013); (Goins et al., } \\
\text { 2010) }\end{array}$ \\
\hline
\end{tabular}

Table 9 Technology options: supportive devices

\section{DISCUSSIONS AND OUTLOOK}

The world's population is ageing rapidly and the cost of caring for older people is also rising. An important feature of population aging is the progressive aging of the older population itself. By 2050, the world will have almost 400 million people aged 80 years or older. As such, the age group of 80 and older has become the fastest growing age segment in the global population (OECD, 2012). Age is a good proxy for high support needs; 40 per cent of those currently aged 85 years and over are estimated to have a sever disability, as measured by their ability to perform their daily activities (Leeson et al., 2004). This means the group of older people with high support needs is growing, as the prevalence of some physical and cognitive conditions such as dementia and movement difficulties is popular among this group.

One approach to above mentioned concern is to maintain the older adults' abilities and skills for their everyday life for a longer period of time, which will decrease the caring costs and increase the quality of life of elderly. In this regard, technologies can play a significant role. Although the research in this matter has been growing and there have been different empirical evidences on contribution of assistive technologies for improvement of elderly's quality of life, the effective potentials of technology in maintaining seniors' abilities need further investigations. In response to the research question, "What are the potentials of assistive technologies for seniors"- we found assistive technology can provide aid for elderly, but are underutilized to offer effective training for skills that may empower seniors for independent living.

Having reviewed the literature in assistive technologies for aged care, this paper has identified two basic categories; direct supportive and indirect empowering technologies. Supportive technologies provide aid to seniors for their everyday life. A primary goal of assistive technologies is to maintain independent lifestyle of older adults. These technologies are usually designed to aid elderly for their daily life. We have found general purpose ICT, robots; online information services, smart home and remote care and supporting devices have been utilized to this end. Empowering technologies take a proactive approach to assist elderly for their independent living. These technologies highlight the fact that we need to not only aid seniors for their daily living activities, but also we should train them to improve their skills over the time. These group utilizing technologies such as games or social media provide facilities for elderly to maintain or improve their physical, cognitive or social skills. 
Despite all the concerns and attempts reported in literature for independent living, less is known on the differentiation of technologies that provide direct support for seniors' daily activities and indirect support through empowering technologies that help the elderly through skills training for independent living. In this paper we consider direct supportive technologies differently to indirect, empowering technologies, for example using brain training through games to improve an older person's resilience so they become less dependent. Another example of empowering technologies is to use social media to empower seniors using internet for expand the circle of friends and avoid the social isolation issues.

The term "empowerment" is a contested notion. It is a very complex term that is difficult to define. (Silva, 1997) refers to empowerment as any process whereby people can gain increased control over their lives. (Narayan et al., 2000) further defines empowerment as any process that enables "selfconfidence, self-direction, autonomy, and self-worth". For the purpose of this paper, empowerment is the process of maintaining a concrete, new capability to perform some specific action (Cornish, 2006). Here empowerment is not seen as an increase in self-confidence or control, rather the ability to take an action. Actions refer to the seniors' daily activities. This view of empowerment implies enabling seniors to develop a range of capabilities (Gigler, 2004), and refers to capability approach (Sen, 1999), that can be utilized in adoption as the process of expanding a choice that lead people to the lives they have reason to value. The implication of this approach in our study is to adopt assistive technologies that build capabilities for seniors to help themselves in their daily activities as opposed to being supported by technologies. This will lead them to maintain their independent living, which they value highly. In this respect, capability theory (Sen, 1999) confirms that technology adoption by seniors empowers them to change and improve their well-being which in turn leads to more independent living. However for adoption to be effective, empowerment of some skills is required. Using capability theory, we can conclude that for seniors to be capable to live independently we must provide them technologies that train and empower their skills related to their everyday life activities. However, as proposed by capability theory, individual, environmental and psychological factors significantly influence this adoption.

From the technology options identified earlier in this paper, we believe games and social media, because of their interactive nature, empowers elderly for their daily living. However, looking at Figure 3, we can see games and social media have been given very limited attention in the research community. We therefore encourage researchers to investigate the adoption of games to empower elderly and help maintain their skills for independent living. We also suggest that the use of capability theory can help in this endeavor.

Games offer complex scenarios that can stimulate discussion, collaboration and imagination, or train skills such as hand-eye coordination, strategic abilities and problem solving. Cognitive training is a set of procedures to help people maintain a useful level of performance in everyday tasks for different functions such as attention, memory, and reasoning, which can be also achieved by games. We believe games can provide cheap and enjoyable off-the-shelf platforms to support cognitive training. While games can empower elderly for their everyday life, physical exercises available through the game platforms e.g. Xbox Kinect can potentially support movement difficulties in older adults.

We can think of several ways that social media can empower seniors to live on their own. A common seniors' refrain is that they would like to stay in touch with their family and friends. Social media can be used as a means by which seniors can use to stay connect with their friends and family while they might suffer from movement or driving difficulties. The importance of socializing as part of a community cannot be overstated, particularly for seniors spending much of their time living isolated at home. It can be critical for those unable to get out of the house to be with others. Social media provides the opportunity to have and be a friend, to congregate without leaving the house, to never be alone even when you are the only one in the house. 
The article concludes that much research has been conducted to directly support elderly in their everyday life while there are avenues of opportunities for empowering elderly and training them to maintain their abilities using assistive technologies that need to be discovered by researchers.

\section{LIMITATIONS}

As is the case with almost any review, this paper has a few limitations that must be kept in mind and these are discussed below.

\section{Quality dependency on the choice of keywords}

This review, like any other literature review, is highly dependent on the keywords that have been chosen and the databases that have been selected for the search. However, in this study, we have conducted a background and exploratory search and keywords and databases were selected according to an experimental method proposed by (Dieste et al., 2009).

\section{Limited resources}

Because realist reviews embrace complexity and seeks to map out the operation of multiple theories in multiple contexts, they can easily grow quite large. Compared to systematic reviews, a realist review, therefore, can only cover a limited number of papers.

\section{Focusing only on publication in $2000-2013$}

The resources that have been selected in this review were only papers published during 2000 and 2013. This decision was made in order to focus of the study on recent developments in the field, it is still arguable that authors may have missed valuable technologies and adoption approaches that are applicable to today's aged care settings.

\section{Nature of the studies that have been reviewed}

In addition to the limitations on resources for this review, there are limitations to the nature of information that could be retrieved. Most studies on the adoption of assistive technologies for aged care are not done from a realist perspective and therefore important details for a realist review about the nature of the intervention and its context may be omitted.

\section{Reliability of the results}

In order to ensure the reliability of the results and avoid bias, we have deployed the proportional reduction in loss (PRL) method. We asked four experts from North America, Australia, Europe and Asia to review both interventions and impacting factors of adoption. However, it is still arguable that the results might have been impacted by subjectivity of the authors as well as the judges.

\section{REFERENCES}

(Boni) Li, Y., Perkins, A., 2007. The impact of technological developments on the daily life of the elderly. Technol. Soc. 29, 361-368. doi:10.1016/j.techsoc.2007.04.004

Abdullah, M.Y., Salman, A., Razak, N.A., Noor, N.F.M., Malek, J.A., 2011. Issues affecting the use of information and communication technology among the elderly: A case study on JENii, in: 2011 IEEE 10th Malaysia International Conference on Communications (MICC). pp. 29-32. doi:10.1109/MICC.2011.6150294

Adams, N., Stubbs, D., Woods, V., 2005. Psychological barriers to Internet usage among older adults in the UK. Inform. Health Soc. Care 30, 3-17. doi:10.1080/14639230500066876 
Ahn, M., Beamish, J.O., Goss, R.C., 2008. Understanding Older Adults' Attitudes and Adoption of Residential Technologies. Fam. Consum. Sci. Res. J. 36, 243-260. doi:10.1177/1077727X07311504

Aula, A., 2005. User study on older adults' use of the Web and search engines. Univers. Access Inf. Soc. 4, 67-81. doi:10.1007/s10209-004-0097-7

Australian Nursing Federation, 2012. Aged Care Can't Wait Report. Australian Nursing Federation.

Barnard, Y., Bradley, M.D., Hodgson, F., Lloyd, A.D., 2013. Learning to use new technologies by older adults: Perceived difficulties, experimentation behaviour and usability. Comput. Hum. Behav. 29, 1715-1724. doi:10.1016/j.chb.2013.02.006

Beer, J.M., Takayama, L., 2011. Mobile remote presence systems for older adults: Acceptance, Benefits, and Concerns, in: 2011 6th ACM/IEEE International Conference on Human-Robot Interaction (HRI)., pp. 19-26.

Bickmore, T.W., Caruso, L., Clough-Gorr, K., 2005a. Acceptance and usability of a relational agent interface by urban older adults, in: CHI'05 Extended Abstracts on Human Factors in Computing Systems, CHI EA '05. ACM, New York, NY, USA, pp. 1212-1215. doi:10.1145/1056808.1056879

Bickmore, T.W., Caruso, L., Clough-Gorr, K., Heeren, T., 2005b. "It”s just like you talk to a friend' relational agents for older adults. Interact. Comput. 17, 711-735. doi:10.1016/j.intcom.2005.09.002

Biljon, J. van, Renaud, K., 2008. A Qualitative Study of the Applicability of Technology Acceptance Models to Senior Mobile Phone Users, in: Song, I.-Y., Piattini, M., Chen, Y.-P.P., Hartmann, S., Grandi, F., Trujillo, J., Opdahl, A.L., Ferri, F., Grifoni, P., Caschera, M.C., Rolland, C., Woo, C., Salinesi, C., Zimányi, E., Claramunt, C., Frasincar, F., Houben, G.-J., Thiran, P. (Eds.), Advances in Conceptual Modeling - Challenges and Opportunities, Lecture Notes in Computer Science. Springer Berlin Heidelberg, pp. 228-237.

Boontarig, W., Chutimaskul, W., Chongsuphajaisiddhi, V., Papasratorn, B., 2012. Factors influencing the Thai elderly intention to use smartphone for e-Health services, in: 2012 IEEE Symposium on Humanities, Science and Engineering Research (SHUSER). pp. 479-483. doi:10.1109/SHUSER.2012.6268881

Braun, M.T., 2013. Obstacles to social networking website use among older adults. Comput. Hum. Behav. 29, 673-680. doi:10.1016/j.chb.2012.12.004

Burnett, J.S., Mitzner, T.L., Charness, N., Rogers, W.A., 2011. Understanding Predictors of Computer Communication Technology Use by Older Adults. Proc. Hum. Factors Ergon. Soc. Annu. Meet. 55, 172-176. doi:10.1177/1071181311551036

Cameron, D.D., Marquis, D.R., Webster, B., 2001. Older adults perceptions, experiences and anxieties with emerging technologies. Australas. J. Ageing 20, 50-56. doi:10.1111/j.17416612.2001.tb00399.x

Carpenter, B.D., Buday, S., 2007. Computer use among older adults in a naturally occurring retirement community. Comput. Hum. Behav. 23, 3012-3024. doi:10.1016/j.chb.2006.08.015

Choi, N.G., Dinitto, D.M., 2013. Internet use among older adults: association with health needs, psychological capital, and social capital. J. Med. Internet Res. 15, e97. doi:10.2196/jmir.2333

Chu, R.J., 2010. How family support and Internet self-efficacy influence the effects of e-learning among higher aged adults - Analyses of gender and age differences. Comput. Educ. 55, 255-264. doi:10.1016/j.compedu.2010.01.011 
Chu Yew Yee, S.L., Duh, H.B.-L., Quek, F., 2010. Investigating narrative in mobile games for seniors, in: Proceedings of the SIGCHI Conference on Human Factors in Computing Systems, CHI '10. ACM, New York, NY, USA, pp. 669-672. doi:10.1145/1753326.1753424

Chung, J.E., Park, N., Wang, H., Fulk, J., McLaughlin, M., 2010. Age differences in perceptions of online community participation among non-users: An extension of the Technology Acceptance Model. Comput. Hum. Behav. 26, 1674-1684. doi:10.1016/j.chb.2010.06.016

Conci, M., Pianesi, F., Zancanaro, M., 2009. Useful, Social and Enjoyable: Mobile Phone Adoption by Older People, in: Gross, T., Gulliksen, J., Kotzé, P., Oestreicher, L., Palanque, P., Prates, R.O., Winckler, M. (Eds.), Human-Computer Interaction - INTERACT 2009, Lecture Notes in Computer Science. Springer Berlin Heidelberg, pp. 63-76.

Conci, M., Pianesi, F., Zancanaro, M., 2010. Older adults' attitude towards a monitoring technology, in: Proceedings of the 28th Annual European Conference on Cognitive Ergonomics, ECCE' 10. ACM, New York, NY, USA, pp. 143-146. doi:10.1145/1962300.1962328

Copolillo, A., Prohaska, T.R., 2001. Older adults' mobility device use after in-patient rehabilitation: Intention, actual use, and need. Phys. Occup. Ther. Geriatr. 19, 35-48. doi:10.1300/J148v19v04_03

Cornish, F., 2006. Empowerment to participate: a case study of participation by indian sex workers in HIV prevention. J. Community Appl. Soc. Psychol. 16, 301-315. doi:10.1002/casp.866

Courtney, K.L., 2008. Privacy and Senior Willingness to Adopt Smart Home Information Technology in Residential Care Facilities. Methods Inf. Med. doi:10.3414/ME9104

Courtney, K.L., Demiris, G., Rantz, M., Skubic, M., 2008. Needing smart home technologies: the perspectives of older adults in continuing care retirement communities. Inform. Prim. Care 16, 195-201.

Czaja, S.J., Charness, N., Fisk, A.D., Hertzog, C., Nair, S.N., Rogers, W.A., Sharit, J., 2006. Factors predicting the use of technology: findings from the Center for Research and Education on Aging and Technology Enhancement (CREATE). Psychol. Aging 21, 333-352. doi:10.1037/08827974.21.2.333

Czaja, S.J., Lee, C.C., Nair, S.N., Sharit, J., 2008. Older Adults and Technology Adoption. Proc. Hum. Factors Ergon. Soc. Annu. Meet. 52, 139-143. doi:10.1177/154193120805200201

DEMIRIS, G., RANTZ, M.J., AUD, M.A., MAREK, K.D., TYRER, H.W., SKUBIC, M., HUSSAM, A.A., 2004. Older adults' attitudes towards and perceptions of "smart home" technologies: a pilot study. MED Inf. 29, 87-94.

Demiris, G., Thompson, H., Boquet, J., Le, T., Chaudhuri, S., Chung, J., 2013. Older adults' acceptance of a community-based telehealth wellness system. Inform. Health Soc. Care 38, 27-36. doi:10.3109/17538157.2011.647938

Dieste, O., Grimán, A., Juristo, N., 2009. Developing search strategies for detecting relevant experiments. Empir. Softw. Eng. 14, 513-539. doi:10.1007/s10664-008-9091-7

DOHA, 2008. Australian Dementia Resources Guide. Australia.

Eastman, J.K., Iyer, R., 2004. The elderly's uses and attitudes towards the Internet. J. Consum. Mark. 21, 208-220. doi:10.1108/07363760410534759

El-Attar, T., Gray, J., Nair, S.N., Ownby, R., Czaja, S.J., 2005. Older Adults and Internet Health Information Seeking. Proc. Hum. Factors Ergon. Soc. Annu. Meet. 49, 163-166. doi:10.1177/154193120504900203

ERA, 2012. The Excellence in Research for Australia (ERA) Initiative.

Ghapanchi, A.H., Aurum, A., 2011. Antecedents to IT personnel's intentions to leave: A systematic literature review. J. Syst. Softw. 84, 238-249. doi:10.1016/j.jss.2010.09.022 
Gigler, B.-S., 2004. Including the Excluded- Can ICTs empower poor communities? Towards an alternative evaluation framework based on the capability approach. Presented at the 4 th International Conference on the Capability Approach, Pavia, Italy.

Giuliani, M.V., Scopelliti, M., Fornara, F., 2005. Elderly people at home: technological help in everyday activities, in: IEEE International Workshop on Robot and Human Interactive Communication, 2005. ROMAN 2005, pp. 365-370. doi:10.1109/ROMAN.2005.1513806

Goins, R.T., Spencer, S.M., Goli, S., Rogers, J.C., 2010. Assistive Technology Use of Older American Indians in a Southeastern Tribe: The Native Elder Care Study. J. Am. Geriatr. Soc. 58, 21852190. doi:10.1111/j.1532-5415.2010.03140.x

Guo, X., Sun, Y., Wang, N., Peng, Z., Yan, Z., 2013. The dark side of elderly acceptance of preventive mobile health services in China. Electron. Mark. 23, 49-61. doi:10.1007/s12525-012-0112-4

Haase, R., Schultheiss, T., Kempcke, R., Thomas, K., Ziemssen, T., 2012. Use and acceptance of electronic communication by patients with multiple sclerosis: a multicenter questionnaire study. J. Med. Internet Res. 14, e135. doi:10.2196/jmir.2133

Häikiö, J., Wallin, A., Isomursu, M., Ailisto, H., Matinmikko, T., Huomo, T., 2007. Touch-based user interface for elderly users, in: Proceedings of the 9th International Conference on Human Computer Interaction with Mobile Devices and Services, MobileHCI '07. ACM, New York, NY, USA, pp. 289-296. doi:10.1145/1377999.1378021

Hanson, V.L., 2010. Influencing technology adoption by older adults. Interact. Comput. 22, 502-509. doi:10.1016/j.intcom.2010.09.001

Hardill, I., Olphert, C.W., 2012. Staying connected: Exploring mobile phone use amongst older adults in the UK. Geoforum 43, 1306-1312. doi:10.1016/j.geoforum.2012.03.016

Heerink, M., 2011. Exploring the influence of age, gender, education and computer experience on robot acceptance by older adults, in: Proceedings of the 6th International Conference on HumanRobot Interaction, HRI '11. ACM, New York, NY, USA, pp. 147-148. doi:10.1145/1957656.1957704

Heerink, M., Ben, K., Evers, V., Wielinga, B., 2008. The Influence of Social Presence on Acceptance of a Companion Robot by Older People. J. Phys. Agents 2, 33-40.

Heerink, M., Krose, B., Evers, V., Wielinga, B., 2006. The Influence of a Robot's Social Abilities on Acceptance by Elderly Users, in: The 15th IEEE International Symposium on Robot and Human Interactive Communication, 2006. ROMAN 2006., pp. 521-526. doi:10.1109/ROMAN.2006.314442

Heerink, M., Kröse, B., Evers, V., Wielinga, B., 2010. Assessing Acceptance of Assistive Social Agent Technology by Older Adults: the Almere Model. Int. J. Soc. Robot. 2, 361-375. doi:10.1007/s12369-010-0068-5

Heerink, M., Krose, B., Wielinga, B., Evers, V., 2008. Enjoyment, intention to use and actual use of a conversational robot by elderly people, in: 2008 3rd ACM/IEEE International Conference on Human-Robot Interaction (HRI). pp. 113-119.

Heinz, M., Martin, P., Margrett, J.A., Yearns, M., Franke, W., Yang, H.-I., Wong, J., Chang, C.K., 2013. Perceptions of technology among older adults. J. Gerontol. Nurs. 39, 42-51. doi:10.3928/00989134-20121204-04

Hernández-Encuentra, E., Pousada, M., Gómez-Zúñiga, B., 2009. ICT and Older People: Beyond Usability. Educ. Gerontol. 35, 226-245. doi:10.1080/03601270802466934

Huang, J.-C., 2011. Exploring the acceptance of telecare among senior citizens: an application of backpropagation network. Telemed. J. E-Health Off. J. Am. Telemed. Assoc. 17, 111-117. doi:10.1089/tmj.2010.0118 
Karavidas, M., Lim, N.K., Katsikas, S.L., 2005. The effects of computers on older adult users. Comput. Hum. Behav. 21, 697-711. doi:10.1016/j.chb.2004.03.012

Kiel, J.M., 2005. The digital divide: Internet and e-mail use by the elderly. Med. Inform. Internet Med. 30, 19-23. doi:10.1080/14639230500066900

Klamer, T., Ben Allouch, S., 2010. Acceptance and use of a social robot by elderly users in a domestic environment, in: Pervasive Computing Technologies for Healthcare (PervasiveHealth), pp. 18. doi:10.4108/ICST.PERVASIVEHEALTH2010.8892

Kubik, S., 2009. Motivations for cell phone use by older Americans. Gerontechnology 8. doi:10.4017/gt.2009.08.03.007.00

Lai, C.K.Y., Chung, J.C.C., Leung, N.K.L., Wong, J.C.T., Mak, D.P.S., 2010. A survey of older Hong Kong people's perceptions of telecommunication technologies and telecare devices. J. Telemed. Telecare 16, 441-446. doi:10.1258/jtt.2010.090905

Lam, J.C.Y., Lee, M.K.O., 2006. Digital Inclusiveness--Longitudinal Study of Internet Adoption by Older Adults. J. Manag. Inf. Syst. 22, 177-206. doi:10.2753/MIS0742-1222220407

Laver, K., Ratcliffe, J., George, S., Burgess, L., Crotty, M., 2011. Is the Nintendo Wii Fit really acceptable to older people?: a discrete choice experiment. BMC Geriatr. 11, 1-6. doi:10.1186/1471-2318-11-64

Law, M., Stewart, D., Letts, L., Pollock, N., Bosch, J., Westmorland, M., 1998a. Guidelines for critical review form- Quantitative Studies.

Law, M., Stewart, D., Letts, L., Pollock, N., Bosch, J., Westmorland, M., 1998b. Guidelines for critical review form- Qualitative Studies.

Leeson, G.W., Harper, S., Levin, S., Britain, G., 2004. Independent living in later life: Literature review. DWP.

Macaulay, A.C., Jagosh, J., Seller, R., Henderson, J., Cargo, M., Greenhalgh, T., Wong, G., Salsberg, J., Green, L.W., Herbert, C.P., Pluye, P., 2011. Assessing the benefits of participatory research: a rationale for a realist review. Glob. Health Promot. 18, 45-48. doi:10.1177/1757975910383936

Mahoney, D.F., 2010. An Evidence-Based Adoption of Technology Model for Remote Monitoring of Elders' Daily Activities. Ageing Int. 36, 66-81. doi:10.1007/s12126-010-9073-0

Mallenius, S., Rossi, M., Tuunainen, V.K., 2007. Factors affecting the adoption and use of mobile devices and services by elderly people - results from a pilot study.

Marshall, M., 1997a. State of the Art in Dementia Care London. U.K.

Marshall, M., 1997b. State of the Art in Dementia Care London. U.K.

McCloskey, D.W., 2006. The Importance of Ease of Use, Usefulness, and Trust to Online Consumers. J. Organ. End User Comput. 18, 47-65. doi:10.4018/joeuc.2006070103

McCreadie, C., Tinker, A., 2005. The acceptability of assistive technology to older people. Ageing Soc. 25, 91-110. doi:10.1017/S0144686X0400248X

McKay, S.M., Maki, B.E., 2010. Attitudes of older adults toward shooter video games: An initial study to select an acceptable game for training visual processing. Gerontechnology Int. J. Fundam. Asp. Technol. Serve Ageing Soc. 9, 5-17. doi:10.4017/gt.2010.09.01.001.00

McLaughlin, A., Gandy, M., Allaire, J., Whitlock, L., 2012. Putting Fun into Video Games for Older Adults. Ergon. Des. Q. Hum. Factors Appl. 20, 13-22. doi:10.1177/1064804611435654

Melenhorst, A.S., Bouwhuis, D.G., 2004. When do older adults consider the internet? An exploratory study of benefit perception. Gerontechnology 3. doi:10.4017/gt.2004.03.02.004.00 
Melenhorst, A.-S., Rogers, W.A., Bouwhuis, D.G., 2006. Older adults' motivated choice for technological innovation: Evidence for benefit-driven selectivity. Psychol. Aging 21, 190-195. doi:10.1037/0882-7974.21.1.190

Melenhorst, A.-S., Rogers, W.A., Caylor, E.C., 2001. The Use of Communication Technologies by Older Adults: Exploring the Benefits from the User's Perspective. Proc. Hum. Factors Ergon. Soc. Апnи. Meet. 45, 221-225. doi:10.1177/154193120104500305

Miskelly, F.G., 2001. Assistive Technology in Elderly Care. Age Ageing 30, 455-458.

Mitzner, T.L., Boron, J.B., Fausset, C.B., Adams, A.E., Charness, N., Czaja, S.J., Dijkstra, K., Fisk, A.D., Rogers, W.A., Sharit, J., 2010. Older adults talk technology: Technology usage and attitudes. Comput. Hum. Behav. 26, 1710-1721. doi:10.1016/j.chb.2010.06.020

Mitzner, T.L., Smarr, C.-A., Beer, J.M., Chen, T.L., Springman, J.M., Prakash, A., Kemp, C.C., Rogers, W.A., 2011. Older Adults' Acceptance of Assistive Robots for the Home.

Morris, A., Goodman, J., Brading, H., 2007. Internet use and non-use: views of older users. Univers. Access Inf. Soc. 6, 43-57. doi:10.1007/s10209-006-0057-5

Mynatt, E.D., Melenhorst, A.-S., Fisk, A.D., Rogers, W.A., 2004. Aware technologies for aging in place: understanding user needs and attitudes. IEEE Pervasive Comput. 3, 36-41. doi:10.1109/MPRV.2004.1316816

Narayan, D., Patel, R., Schafft, K., Rademacher, A., Koch-Schulte, S., 2000. Voices of the poor: Can anyone hear us? Oxford University Press for the World Bank, New York.

Nayak, L.U.S., Priest, L., White, A.P., 2010. An application of the technology acceptance model to the level of Internet usage by older adults. Univers. Access Inf. Soc. 9, 367-374. doi:10.1007/s10209-009-0178-8

Neven, L., 2010. "But obviously not for me": robots, laboratories and the defiant identity of elder test users. Sociol. Health Illn. 32, 335-347. doi:10.1111/j.1467-9566.2009.01218.x

Neves, B.B., 2012. Too old for technology? How the elderly of Lisbon use and perceive ICT. J. Community Inform. 8.

Ng, J., Tan, O., Wong, A., Kiat, K.W., 2012. Older adults' attitudes toward homes service robots, in: Proceedings of the Workshop at SIGGRAPH Asia, WASA '12. ACM, New York, NY, USA, pp. 87-90. doi:10.1145/2425296.2425312

OECD, 2012. World Population Ageing: 1959-2050. Paris.

Or, C.K.L., Karsh, B.-T., Severtson, D.J., Burke, L.J., Brown, R.L., Brennan, P.F., 2011. Factors affecting home care patients' acceptance of a web-based interactive self-management technology. J. Am. Med. Inform. Assoc. 18, 51-59. doi:10.1136/jamia.2010.007336

Pan, S., Jordan-Marsh, M., 2010. Internet use intention and adoption among Chinese older adults: From the expanded technology acceptance model perspective. Comput. Hum. Behav. 26, 1111-1119. doi:10.1016/j.chb.2010.03.015

Pawson, R., Greenhalgh, T., Harvey, G., Walshe, K., 2005. Realist review - a new method of systematic review designed for complex policy interventions. J. Health Serv. Res. Policy 10, 21-34. doi:10.1258/1355819054308530

Peeters, J.M., de Veer, A.J.E., van der Hoek, L., Francke, A.L., 2012. Factors influencing the adoption of home telecare by elderly or chronically ill people: a national survey. J. Clin. Nurs. 21, 31833193. doi:10.1111/j.1365-2702.2012.04173.x

Phang, C.W., Sutanto, J., Kankanhalli, A., Li, Y., Tan, B.C.Y., Teo, H.-H., 2006. Senior Citizens' Acceptance of Information Systems: A Study in the Context of e-Government Services. IEEE Trans. Eng. Manag. 53, 555-569. doi:10.1109/TEM.2006.883710 
Porteus, J., Brownse, S.J., 2000. Exploring Technologies for Independent Living for Older People. Anchor Trust.

Price, M.M., Pak, R., Müller, H., Stronge, A., 2013. Older adults' perceptions of usefulness of personal health records. Univers. Access Inf. Soc. 12, 191-204. doi:10.1007/s10209-012-0275-y

Reeder, B., Demiris, G., Marek, K.D., 2013. Older adults' satisfaction with a medication dispensing device in home care. Inform. Health Soc. Care. doi:10.3109/17538157.2012.741084

Renaud, K., van Biljon, J., 2008. Predicting technology acceptance and adoption by the elderly: a qualitative study, in: Proceedings of the 2008 Annual Research Conference of the South African Institute of Computer Scientists and Information Technologists on IT Research in Developing Countries: Riding the Wave of Technology, SAICSIT '08. ACM, New York, NY, USA, pp. 210219. doi:10.1145/1456659.1456684

Rosenberg, L., Kottorp, A., Winblad, B., Nygård, L., 2009. Perceived difficulty in everyday technology use among older adults with or without cognitive deficits [WWW Document]. URL http://informahealthcare.com/doi/abs/10.3109/11038120802684299 (accessed 6.21.13).

Rust, R.T., Cooil, B., 1994. Reliability Measures for Qualitative Data: Theory and Implications. J. Mark. Res. 31, 1-14. doi:10.2307/3151942

Ryu, M.-H., Kim, S., Lee, E., 2009. Understanding the factors affecting online elderly user's participation in video UCC services. Comput. Hum. Behav. 25, 619-632. doi:10.1016/j.chb.2008.08.013

Salovaara, A., Lehmuskallio, A., Hedman, L., Valkonen, P., Näsänen, J., 2010. Information technologies and transitions in the lives of 55-65-year-olds: The case of colliding life interests. Int. J. Hum.-Comput. Stud. 68, 803-821. doi:10.1016/j.ijhcs.2010.06.007

Sarkisian, G.P., Melenhorst, A.-S., Rogers, W.A., Fisk, A.D., 2003. Older Adults' Opinions of a Technology-Rich Home Environment: Conditional and Unconditional Device Acceptance. Proc. Hum. Factors Ergon. Soc. Annu. Meet. 47, 1800-1804. doi:10.1177/154193120304701505

Sayago, S., Sloan, D., Blat, J., 2011. Everyday use of computer-mediated communication tools and its evolution over time: An ethnographical study with older people. Interact. Comput. 23, 543-554. doi:10.1016/j.intcom.2011.06.001

Selwyn, N., 2004. The information aged: A qualitative study of older adults' use of information and communications technology. J. Aging Stud. 18, 369-384. doi:10.1016/j.jaging.2004.06.008

Selwyn, N., Gorard, S., Furlong, J., Madden, L., 2003. Older adults' use of information and communications technology in everyday life. Ageing Soc. 23, 561-582. doi:10.1017/S0144686X03001302

Sen, A., 1999. Commodities and Capabilities (OUP Catalogue). Oxford University Press.

Silva, L., 1997. Power and politics in the adoption of information systems by organisations: the case of a research centre in Latin America (PhD). The London School of Economics and Political Science (LSE).

Singh, H., Fox, S.A., Petersen, N.J., Shethia, A., Street, R.L., 2009. Older Patients' Enthusiasm to Use Electronic Mail to Communicate With Their Physicians: Cross-Sectional Survey. J. Med. Internet Res. 11. doi:10.2196/jmir.1143

Sintonen, S., Immonen, M., 2013. Telecare services for aging people: Assessment of critical factors influencing the adoption intention. Comput. Hum. Behav. 29, 1307-1317. doi:10.1016/j.chb.2013.01.037 
Smarr, C.-A., Prakash, A., Beer, J.M., Mitzner, T.L., Kemp, C.C., Rogers, W.A., 2012. Older Adults' Preferences for and Acceptance of Robot Assistance for Everyday Living Tasks. Proc. Hum. Factors Ergon. Soc. Annu. Meet. 56, 153-157. doi:10.1177/1071181312561009

Smith, R., Quine, S., Anderson, J., Black, K., 2002. Assistive devices: self-reported use by older people in Victoria. Aust. Health Rev. 25, 169-177.

Southall, K., Gagné, J.-P., Leroux, T., 2006. Factors that influence the use of assistance technologies by older adults who have a hearing loss. Int. J. Audiol. 45, 252-259. doi:10.1080/14992020500258586

Steele, R., Lo, A., Secombe, C., Wong, Y.K., 2009a. Elderly persons' perception and acceptance of using wireless sensor networks to assist healthcare. Int. J. Med. Inf. 78, 788-801. doi:10.1016/j.ijmedinf.2009.08.001

Steele, R., Lo, A., Secombe, C., Wong, Y.K., 2009b. Elderly persons' perception and acceptance of using wireless sensor networks to assist healthcare. Int. J. Med. Inf. 78, 788-801. doi:10.1016/j.ijmedinf.2009.08.001

Steele, R., Secombe, C., Brookes, W., 2006. Using Wireless Sensor Networks for Aged Care: The Patient's Perspective, in: Pervasive Health Conference and Workshops, 2006. pp. 1-10. doi:10.1109/PCTHEALTH.2006.361661

Stojmenova, E., Debevc, M., Zebec, L., Imperl, B., 2013. Assisted living solutions for the elderly through interactive TV. Multimed. Tools Appl. 1-15. doi:10.1007/s11042-011-0972-1

Sum, S., Mathews, R.M., Hughes, I., 2009. Participation of older adults in cyberspace: How Australian older adults use the Internet. Australas. J. Ageing 28, 189-193. doi:10.1111/j.17416612.2009.00374.x

Sum, S., Mathews, R.M., Hughes, I., Campbell, A., 2008. Internet Use and Loneliness in Older Adults. Cyberpsychol. Behav. 11, 208-211. doi:10.1089/cpb.2007.0010

Umemuro, H., 2004. Lowering elderly Japanese users' resistance towards computers by using touchscreen technology. Univers. Access Inf. Soc. 3, 276-288. doi:10.1007/s10209-004-0098-6

Umemuro, H., 2004. Computer attitudes, cognitive abilities, and technology usage among older Japanese adults. Gerontechnology 3. doi:10.4017/gt.2004.03.02.002.00

Van Hoof, J., Kort, H.S.M., Rutten, P.G.S., Duijnstee, M.S.H., 2011. Ageing-in-place with the use of ambient intelligence technology: Perspectives of older users. Int. J. Med. Inf. 80, 310-331. doi:10.1016/j.ijmedinf.2011.02.010

Vichitvanichphong, S., Talaei-Khoei, A., Kerr, D., Ghapanchi, A.H., 2013. Literature Survey "Challenges in Assistive Technologies for Aged Care". Hawaiian Conference of System Sciences (HICSS-47).

Walsh, K., Callan, A., 2011. Perceptions, Preferences, and Acceptance of Information and Communication Technologies in Older-Adult Community Care Settings in Ireland: A CaseStudy and Ranked-Care Program Analysis. Ageing Int. 36, 102-122. doi:10.1007/s12126-0109075-y

Wilkowska, W., Ziefle, M., 2009. Which Factors Form Older Adults' Acceptance of Mobile Information and Communication Technologies?, in: Holzinger, A., Miesenberger, K. (Eds.), HCI and Usability for E-Inclusion, Lecture Notes in Computer Science. Springer Berlin Heidelberg, pp. 81-101.

Wong, A.M.K., Chang, W.-H., Ke, P.-C., Huang, C.-K., Tsai, T.-H., Chang, H.-T., Shieh, W.-Y., Chan, H.-L., Chen, C.-K., Pei, Y.-C., 2012. Technology acceptance for an Intelligent Comprehensive Interactive Care (ICIC) system for care of the elderly: a survey-questionnaire study. PloS One 7, e40591. doi:10.1371/journal.pone.0040591 
Wood, E., Willoughby, T., Rushing, A., Bechtel, L., Gilbert, J., 2005. Use of Computer Input Devices by Older Adults. J. Appl. Gerontol. 24, 419-438. doi:10.1177/0733464805278378

Xue, L., Yen, C.C., Chang, L., Chan, H.C., Tai, B.C., Tan, S.B., Duh, H.B.L., Choolani, M., 2012. An exploratory study of ageing women's perception on access to health informatics via a mobile phone-based intervention. Int. J. Med. Inf. 81, 637-648. doi:10.1016/j.ijmedinf.2012.04.008

Zaad, L., Allouch, S.B., 2008. The Influence of Control on the Acceptance of Ambient Intelligence by Elderly People: An Explorative Study, in: Aarts, E., Crowley, J.L., Ruyter, B. de, Gerhäuser, H., Pflaum, A., Schmidt, J., Wichert, R. (Eds.), Ambient Intelligence, Lecture Notes in Computer Science. Springer Berlin Heidelberg, pp. 58-74. 